\title{
ADMINISTRATIVE AND LEGAL BASES OF CONSUMER RIGHTS PROTECTION ON THE INTERNET
}

\author{
Svitlana Shymon ${ }^{1}$ \\ Iryna Baliuk ${ }^{2}$ \\ Pavlo Kykot ${ }^{3}$ \\ Larysa Shatalova ${ }^{4}$ \\ Yuriy Harust ${ }^{5}$
}

Abstract: The relevance of this article is due to the extremely high rate of development of information and telecommunication technologies, which leads to the urgent need to regulate relationships in the Internet. The purpose of the article is to conduct a scientific study on the legal bases for the existence and development of Internet commerce in Ukraine and to outline the administrative and legal mechanisms of consumer protection in the Internet space. The leading research methods are general scientific and specific research methods, including methods of logic, analysis, comparison. The results of this study are to identify innovative ways to protect the rights of domestic consumers and ways to improve Ukrainian legislation during trading operations in cyberspace. The significance of the obtained results is reflected in the fact that this study may serve as a basis for outlining future changes to the current legislation of Ukraine on trade transactions in the cyberspace of Ukraine.

Keywords: cyberspace of Ukraine, ecommerce, protection of consumer rights, trade transactions in the cyberspace, legal regulation.

\section{Introduction}

Nowadays, there is virtually no resident in our country who does not use the Internet. An important role in this is played by the availability of mobile Internet and increased coverage, which allows Ukrainians to spend more time on the Internet for their

Kyiv National Economic University named after Vadym Hetman, Peremogy Avenue, 54/1, Kyiv, 03057, ${ }^{1}$ Ukraine. E-mail: s.shymon@ politechnika.pro

Kyiv National Economic University named after Vadym Hetman, Peremogy Avenue, 54/1, Kyiv, 03057, ${ }^{2}$ Ukraine

Kyiv National Economic University named after Vadym Hetman, Peremogy Avenue, 54/1, Kyiv, 03057, ${ }^{3}$ Ukraine

Kyiv National Economic University named after Vadym Hetman, Peremogy Avenue, 54/1, Kyiv, 03057, ${ }^{4}$ Ukraine

Sumy State University, Rymskogo-Korsakova Street, 2, Symy, 40007, Ukraine ${ }^{5}$ 
favorite activities. As V.P. Chaikovska states: "Internet penetration in Ukraine annually increases by an average of $5 \%$. In 2015 , the figure was 49\%. As of February 2016, 63\% of households (excluding Crimea) are connected to the Internet in Ukraine. Regularly, once a month or more, $62 \%$ of families use the Internet" (Chaikovska, 2016). According to the results of 2018, the number of Internet users in Ukraine is $70 \%$ of Ukrainians (compared to $63 \%$ as of December 2017), according to the study of the Constituent study 2018 Kantar TNS (The number of Internet users...2019). Factum Group research company claims that the number of Internet users in Ukraine reached $73 \%$ of the total number of Ukrainians in 2019, and the number of regular Internet users at the beginning of the 4th quarter 2019 was 22.96 million (Factum Group, 2019).
As part of the global network, the Ukrainian cyberspace is actively developing. With the availability of new technologies, the influx of new users is increasing, and they are increasingly starting to make online purchases. Currently, Ukrainians are actively using the Internet. Thus, according to the estimates of the international agency "We are social", $58 \%$ of the population of Ukraine regularly uses the services of the Internet. A Google study claims that $66 \%$ of the population uses the Internet to meet their own goals. This figure is growing compared to previous years, in addition to the global trends and development, Internet availability, these indicators are quite good. According to Internet World Stats (Figure 1), Ukraine ranks 29 th among countries in the world by number of users (Chuiko, 2017).

Figure 1: The ratio of the number of Internet users to the total population of countries (2015-2019)

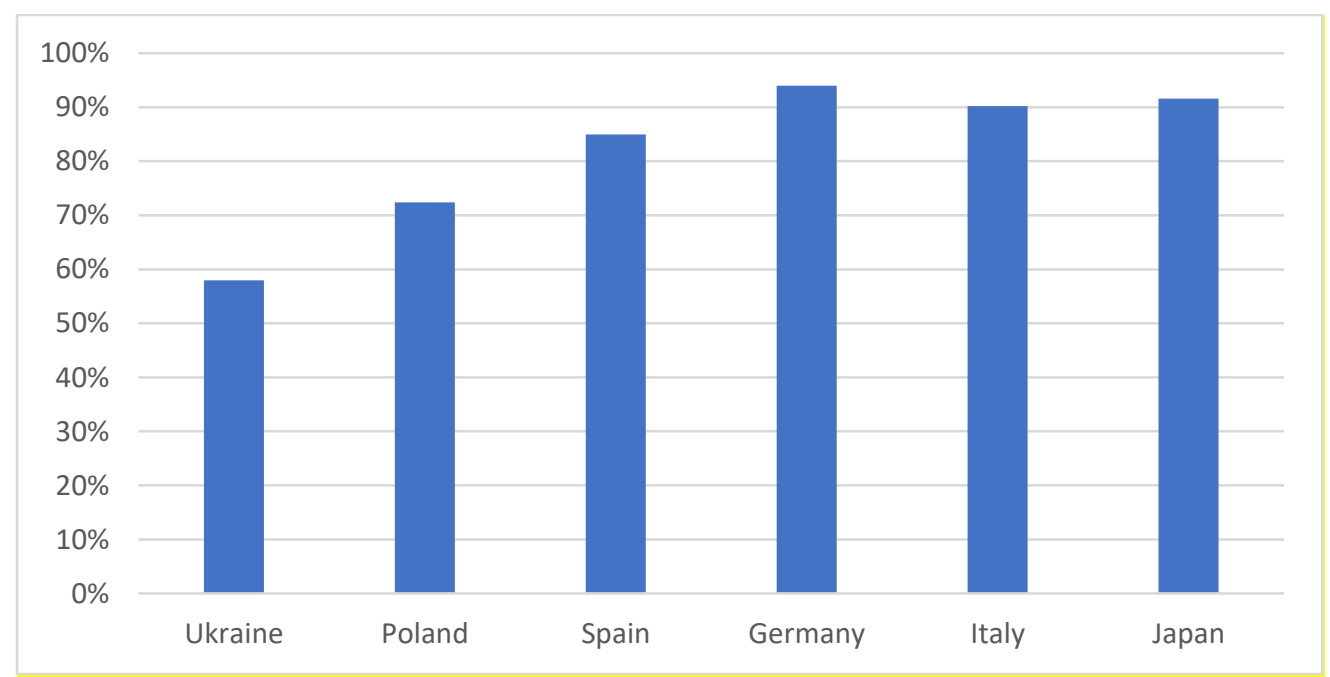

Approximately $45 \%$ of all online shoppers make purchases through social networks at least once. Facebook is in the lead, which is not surprising. According to 
Comfy.ua, eight out of ten people who buy a product in a store search for it first through Google search, reading reviews, characteristics and comparing prices. According to Google statistics, it is natural for $85 \%$ of users to use multiple devices to make the same purchase. The number of products in the Rozetka online hypermarket assortment reached 1.2 million positions in 2017 (Fedorychak, 2018). Amazon, AliExpress and eBay are among the three most popular among Ukrainians online stores.

The rapid development of Internet commerce and the number of participants in this market actively increases the number of legal relationships in this segment and requires appropriate legal support, and control over the observance of participants' rights by the state (Harust et al., 2019a). In this regard, the aim of the study is to analyze the features of the legal regulation of electronic commerce in Ukraine and determine ways to protect consumer rights in the framework of the current Ukrainian legislation.

\section{Materials and Methods}

During the study, the following methods were used: general theoretical (analysis, synthesis, concretization, generalization, analogy method, modeling) when reviewing the literature and statistical data to conduct a comparative analysis of the popular indicators of the Internet, and in particular, e-commerce, among the population of developed countries of the world and Ukraine and analysis of the legal regulation of these processes by the legislation of these countries. Specific empirical methods were also used to study the institute of consumer protection during trade operations in the cyberspace of Ukraine, as well as in the study of regulatory and scientific and methodological literature on this issue.

The Internet, which emerged as a project of the US Department of Defense, later evolved into a global medium of communication and online commerce. Nowadays, more and more commercial relationships are moving to the fast-growing Internet and are primarily focused on the needs of the buyer. Let's consider in more detail the features of the development of electronic commerce in the world.

E-commerce has been showing steady growth every year: from 2010 to 2017 its commodity-cash turnover increased 6.5 times. In 2016, the largest volume of e-commerce in the world reached China (\$337 billion), slightly lower in the United States (\$ 251 billion), followed by the United Kingdom (\$ 67 billion) and Japan (\$ 38 billion) (Poliakh et al., 2017). 
The volume of the Ukrainian ecommerce market is substantially smaller than in the above mentioned countries, the European Union, the Russian Federation or even the Republic of Poland, but the growth of this market in developed countries is at the level of $20 \%$, in Ukraine in recent years it is much higher (Figure 2). According to Web
Mashina, the Ukrainian online sales market in 2020 should reach $\$ 15$ billion. This data is quite low compared to the leading countries. In the United States, \$ 400 billion is expected in 2020. However, on average, the volume of Ukrainian online market grows by $4.1 \%$ every year (Poliakh et al. 2017).

Figure 2: E-commerce market volume in Ukraine and abroad

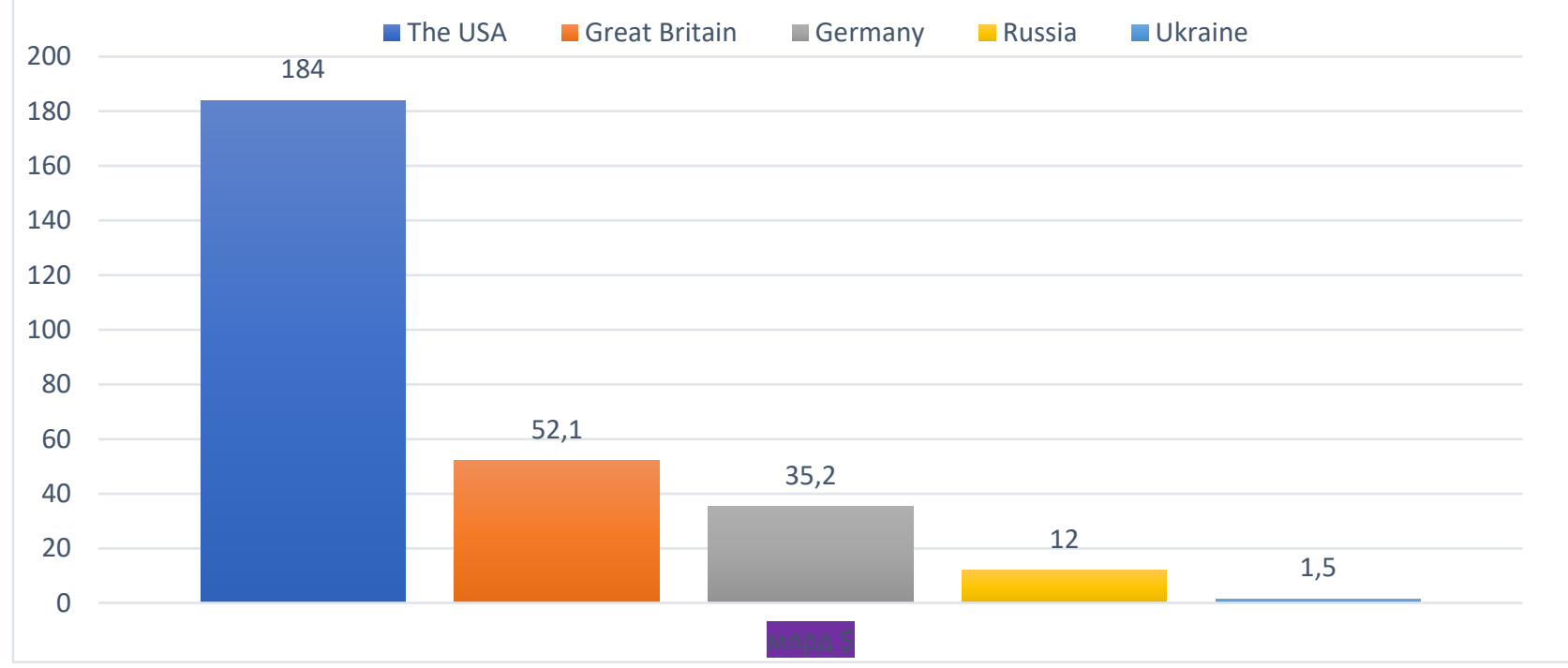

According to expert estimates, the share of e-commerce in Ukraine today is about $3 \%$ of all retail trade. In most developed countries, the figure is $10-15 \%$, so the potential for growth is enormous. The main trends that were present in the Ukrainian e-commerce market and influenced its growth in 2017 include:

- $\quad$ further expansion of the Internet has led to an increase in the number of active online shoppers, especially due to the increase in the number of shoppers living in small towns and villages;

- $\quad$ the expansion of $3 \mathrm{G}$ coverage and the increase in the number of mobile devices has led to the fact that $47 \%$ of Internet users are accessing the network from mobile devices and this proportion is constantly growing;

- $\quad$ increasing the number of marketplaces (trading floors where manufacturers and sellers can place their products for sale); 
- increasing the number of goods delivery services, the range and quality of services they provide.

However, the main factor in the rapid development of domestic online commerce in 2019-2020 was and continues to be personalization, when offers and recommendations are provided for each of the customer segments, taking into account individual needs and wishes of consumers. This has become a driving force in increasing e-commerce loyalty among active and potential buyers (Figure 3). Increased collaboration of online stores with institutions that can provide credit to shoppers could increase e-commerce sales, as online loans make only a few percent of total purchases. Loans can have many benefits to an online store, including increasing sales by $5-10 \%$ and increasing the average check by $20-25 \%$ (Chaikovska, 2016).

Figure 3: Number of Internet shoppers from the general audience of Internet users

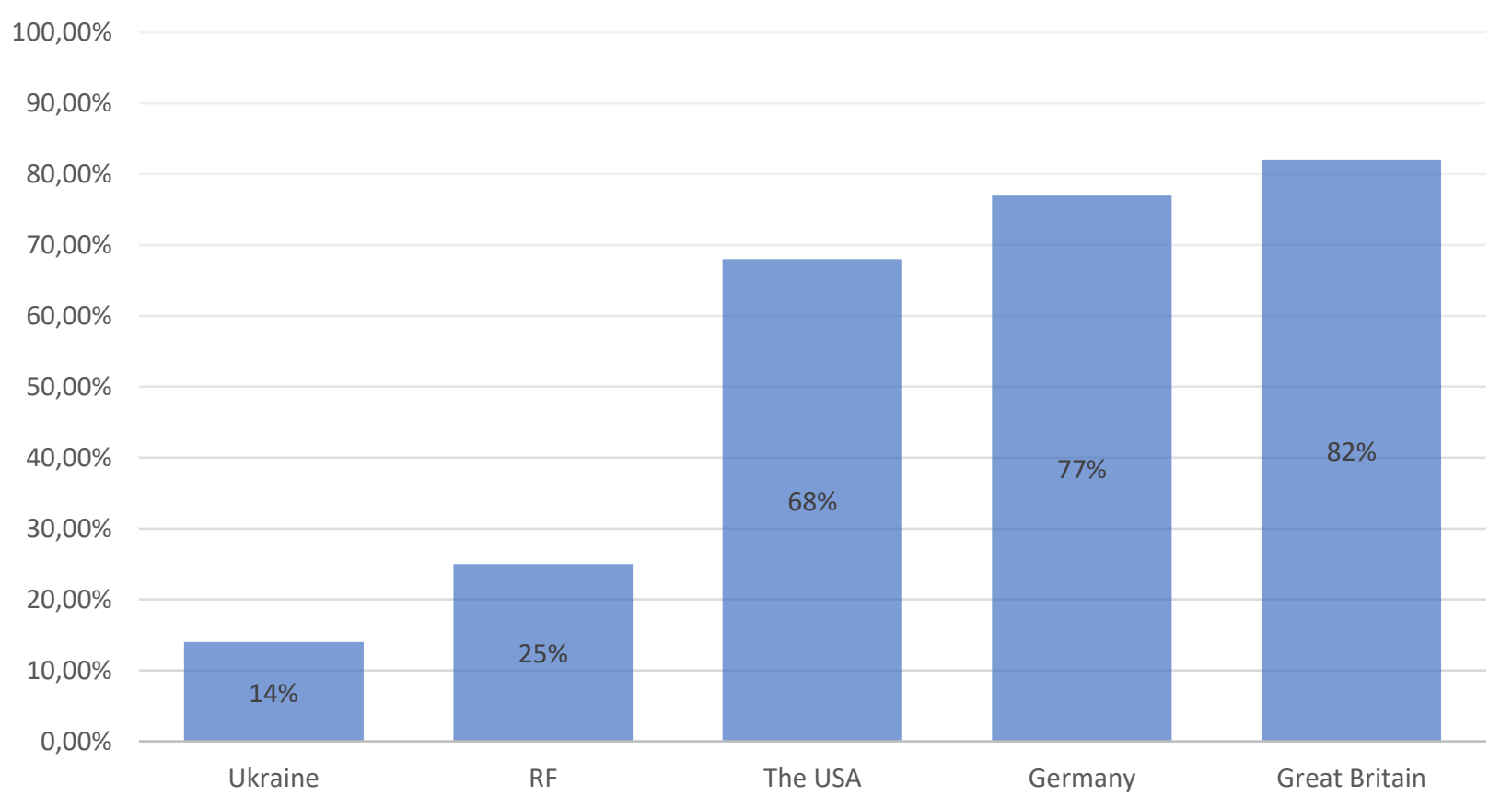


According to AG. Marketing: "The largest group of sites in the online trading segment are EVO projects Prom.ua, Bigl.ua, Crafta.ua, Shafa.ua. All of these sites are marketplaces. Last year Ukrainians spent 14.2 billion hryvnias on them, which is almost $70 \%$ more than a year ago" (Fedorychak, 2018). On average, $31 \%$ of Ukrainians have bought goods online at least once. That's about 7 million people. Through marketplaces of EVO (Ukrainian product IT company), Ukrainians most often buy online products of the following groups: clothing, shoes and accessories, equipment and electronics, home and garden supplies. In 2017, "Nova Poshta" LLC delivered approximately 30 million parcels from online stores, which is one third more than in 2016 (Chuiko, 2017).

According to GfK (the largest market research institute in Germany), the list of the most popular categories of goods that Ukrainians buy online is as follows: most Ukrainians prefer home appliances, computers and electronics, but this figure is starting to decline recently, as is clothing that Ukrainians are less likely to buy. Children's products, cosmetics, perfumes, accessories and gifts have strong positions. The number of orders of ready meals is increasing. The positions of medical products, including contact lenses, are quite low (Official Consumer Confidence Statistics, 2018). In fact, there is no difference between EVO and GfK data.

According to Prom.ua and Bigl.ua, the most promising niches in online commerce in the near future will be: everyday goods, food, raw materials, electrical equipment, pet supplies (Zhylenko, 2018). The top 10 most visited websites of Ukraine include three sites related to online commerce: OLX.ua, Rozetka.com.ua, Prom.ua (Zhylenko, 2018).

With such impressive statistics on the development and growth of the online commerce segment, there also are certain levers of restraint. According to Kantar TNS, the biggest problem for the consumer is the inability to physically contact the product. Returning to the above given statistics, the bulk of online purchases are purchases of clothing products. This type of product is quite difficult to buy without direct physical 
contact. Second place is the fear of buyers to leave personal information and distrust of online stores. This problem in practice is quite easy to "cure" by the reputation of the online store. Customers who used online shopping services tend to value them highly enough and recommend to their surroundings. Among other reasons that discourage Ukrainians from shopping online are the desire to receive the goods immediately, ignorance of how to shop online, the desire to go shopping with friends, and the fear of getting non-branded items at a brand price.

It should also be noted that the number and activity of online shoppers is influenced by emotional and functional characteristics. Thus, among the functional characteristics of the leading place is free shipping, the presence of goods in the warranty, short delivery time, availability of comments on this type of product, a convenient search for a product on the site, convenient terms of return. These characteristics are most often noticed by the buyer when choosing an online store. Features such as the presence of a warranty on the goods and the availability of comments are usually associated with buyers' distrust of the websites, so most often the buyer first pays attention to them (Zhylenko, 2019).

Emotional features include low prices, high quality products, good service, recommendations from friends, and online shopping to be the market leader (Harust et al., 2019b). Thus, most often Ukrainians pay attention to the price of the product, and only then interested in the safety and reputation of this online store. This is largely due to the economic situation in the country and some of the issues that arise in practice, but are not regulated by law, which creates vulnerability of the population.

It can be noted that Ukraine has a sufficiently developed legal framework capable of regulating a wide range of relations arising in the Internet environment, but a certain segment of social relations is currently not regulated by domestic legislation. Thus, the issue of protecting consumer rights in online commerce is quite acute, since not all of its subjects comply with the requirements of the law, with consumers at the risk of not only receiving poor quality goods, but even losing money without receiving anything in general (Myrhorod-Karpova et al., 2019). 


\section{Results and Discussion}

After the distribution of the Internet within the administrative border of Ukraine, the domestic legislation changed accordingly. Thus, the main foundations for regulating public relations in the field of e-commerce were laid in the early 2000s by the adoption of the Civil Code of Ukraine (2003), the Economic Code of Ukraine (2003), Law of Ukraine "On electronic documents and electronic document management" No. 851-IV (2003), Law of Ukraine “On electronic digital signature" No. 852-IV (2003) and Law of Ukraine "On consumer protection” No. 1023-XII (1991).

In 2007, the Verkhovna Rada of Ukraine adopted the Law of Ukraine "On basic principles of information society development in Ukraine for 2007-2015" dated 09.01.2007 No. 537-V. This normative and legal act has laid the basis for the development of the information society and contains provisions recognizing the development of cyberspace as a priority: "state support for new "electronic" sectors of the economy (trade, financial and banking services, etc.)" (2007). The Order of the
Ministry of Economy and Development of Ukraine No. 103 approved the "Rules for the sale of goods on order and outside commercial or office space", which gave the definition of distance trading, namely, stated that "distance trade is a form of sale of goods outside commercial or office space, under which the choice of goods and their orders do not coincide in time with the direct transmission of the selected product to the consumer" (2007).

The real breakthrough was the adoption in 2015 of the Verkhovna Rada of Ukraine of the Law of Ukraine "On Ecommerce" No. 675-VIII (2015), which establishes the organizational and legal bases of activity in the field of ecommerce, regulates the procedure and conditions for committing electronic transactions. It should be noted that it was this legislative act that first provided the definition of the concept of ecommerce, because before that there was only a doctrinal definition. Thus, in accordance with paragraph 1, Part 1 of Art. 3 of this Law, e-commerce is a profit-seeking relationship arising out of a transaction to acquire, modify or terminate civil rights and responsibilities remotely using information and 
telecommunication systems, whereby the participants in such a relationship rights and obligations of property character" (2015).

At the same time, we consider it necessary to emphasize that the Law of Ukraine "On E-Commerce" dated 03.09.2015 No. 675-VIII does not cover such public relations as: provision of banking services, issuance and circulation of electronic money, transfer of funds, mechanism for collecting and disseminating information. These issues are regulated by other legal acts, namely: Law of Ukraine "On payment systems and funds transfer in Ukraine" No. 2346III (2001), Law of Ukraine “On financial services and state regulation of financial services markets" No. 2664-III (2001), Law of Ukraine "On banks and banking" No. 2121-III (2000), Law of Ukraine “On insurance" No. 85/96-BP (1996), Law of Ukraine "On consumer protection" No. 1023-XII (1991), Law of Ukraine "On advertising" No. 270/96BP (1996), Law of Ukraine "On information protection in information and telecommunication systems" No. 80/94-VR (1994), Law of Ukraine "On telecommunications" No. 1280-IV (2003), Law of Ukraine "On protection of personal data" No. 2297-VI (2010) and other normative and legal acts.

Despite such a large number of legislative and regulatory acts, it should be noted that the problem of legal regulation of the e-commerce sphere in Ukraine is still unresolved. However, according to $\mathrm{Z}$. Zadorozhnyi: "Ecommerce in Ukraine is the most regulated at the legislative level the type of business that is carried out in the electronic environment" (Zadorozhnyi, 2017). It is difficult to disagree with this statement, since a large number of regulations regulate relationships in the Internet environment; however, they have been adopted gradually and regulate only certain aspects. The superfast pace of information technology development, the expansion of virtual borders, leads to a large number of users who are constantly implementing their ideas, which are completely new and unregulated domestic legislation, because the Ukrainian Parliament, because of its inertia, is unable to respond to changes in a timely manner in cyberspace. Thus, the Law "On ECommerce" adopted in 2015 has long been in need of amendments. First of all, this concerns the list of e-commerce 
business entities, which include the seller (contractor, supplier) of goods, works, services in e-commerce, and the buyer (customer, consumer) of goods, works, services in e-commerce, information service providers, public authorities and local self-government bodies in the performance of their functions as state or local self-government (2015).

The legal framework governing public relations in the field of ecommerce generally has a positive impact on the development of this field of business. However, quite often ecommerce entities neglect the requirements and rules set by current law, thereby endangering themselves and their property, thereby creating real opportunities for crime or other offense. Investigating this issue, we came to the conclusion that shoppers in online stores are exposing themselves to three major types of danger:

1) the danger is related to the use of personal data provided during the purchase;

2) the risk of financial transactions, the risk of losing money;

3) danger related to the quality of the product.
How can the consumers protect their rights in the online store and not be endangered? According to the Law of Ukraine "On consumer protection" (2017) the buyer is equal in scope of his rights and obligations to the consumer in the case of concluding a contract outside commercial or office premises and concluding a distance contract.

The said legislative act establishes the norm that the document confirming the transaction should serve as a contract concluded between the service provider, the product and its consumer. This contract shall contain the following provisions: date of conclusion of the contract; the name and location of the seller (artist); product name; the price; term of performance of works (provision of services); rights and obligations of the parties to the contract. The contract should be considered an oral or written transaction between the consumer and the seller (performer) about the quality, terms, price and other conditions under which the products are sold. Confirmation of the oral transaction is issued by receipt, merchandise or cash receipt, ticket, coupon or other documents (2017). 
Despite the fact that the legal rules are created to protect the consumer's rights and defend his/her position, but in fact they do not operate in the conditions of today. As an example, the use of mail services when receiving an online order, but the Law of Ukraine "On E-Commerce" does not apply to the public relations entities that arise in the field of e-commerce mail, leaving its status uncertain. It could be attributed to an intermediate service provider, but based on the definition given by the legislator, this statement is incorrect (2015).

Uncertainty is also the situation regarding the regulation of relationships in the case of courier delivery of online orders, since a large part of the population uses the Internet to buy ready-made food delivered within the city to a buyer using courier delivery services. Again, the status of couriers, as well as mail, is uncertain, as they cannot be attributed to intermediate service providers. Usually they represent the interests of the seller, the provider of certain services, in such a case, the person may be identified with the person he/she represents, since for the buyer he/she is the representative of the entity with which the contract was concluded and, as a rule, the courier himself accepts money from the person who received their services.

More complicated is the situation with online stores selling digital alphanumeric keys for software or other codes to activate the software. These sites are usually created by young entrepreneurs without any legal requirements. Typically, such websites do not find any data that is required to be known to the buyer. Finding out why these websites work and at least some contact information is not possible because they are not listed. This situation can be shown by the example of the online store Zaka-Zaka.com. This e-shop does not provide any information about the legal entity, its location and other relevant data that can be used in case of violation of consumer rights and in the procedure of violated rights protection. Interesting in the consideration of this issue is the "User Agreement" created by the administration of the website, which, as stated in paragraph 1.2 , regulates the relationship between the administration of the site and users. This agreement states that the buyer has the right to return the goods purchased on this 
website "due to the inability of the site administration to fulfill its obligations". If the product is of good quality but does not satisfy the consumer, for example in their size, then it can no longer be returned. This provision is contrary to the Law of Ukraine "On consumer protection", namely Part 1 of Art. 9 of the Law, and guided by Part 1 of Art. 203 of the Civil Code of Ukraine (2003) it can be argued that entering into transactions under such conditions automatically leads to their void. Unfortunately, this attitude of unscrupulous entrepreneurs to the legislation and their consumers is quite widespread in the Internet environment, so there is a need to create a mechanism to protect consumers from such potential danger.

Given that Ukraine is becoming an active member of the global cyberspace, there is a need to resolve as soon as possible the problem of legal regulation of public relations in the Internet environment (Harust et al., 2019c). Currently, there is a regulatory framework governing certain ecommerce spectrum. There are precedents when certain websites that violate current law continue to operate, and any Ukrainian has the opportunity to access it. Therefore, in our opinion, solving the above problems is a priority of our legislation in this area.

It is inappropriate to regulate public relations in only one segment of cyberspace, which is Ukraine. Most research scientists are inclined to believe that the solution to the problem of insufficient legal regulation of the Internet network functioning, and as a consequence of inadequate protection of consumer rights in it, is possible only on a global scale. As the Internet emerged and was created as a world phenomenon, despite its initial purpose, it became independent of any state. Making online transactions is blurring the borders, as Ukrainians can easily buy items made in the European Union or the United States through Internet websites. However, the legal approach to regulating the status of e-commerce entities varies across countries.

Thus, in the US public relations on the Internet are regulated through the programs ICANN (Internet Corporation for Assigned Names and Numbers), IANA (Internet Assigned Numbers), ISOC (Internet Society), IETF (Internet Engineering Task Force). These 
programs are designed to address issues that arise in particular industries and elements of cyberspace. This practice is applied only at the state level, but in the long run such implementation of these programs could lead to an improvement of the regulatory climate in cyberspace as a whole. The mechanism of legislative regulation of public relations in the US online network, is characterized by detailed regulation of a large number of public relations, and a relatively low level of state intervention, the method of creating certain organizations.

Among the US legislation it is necessary to outline the "Model law on electronic transactions" (1999), “On electronic signatures in international and domestic trade relations" (2000), "On information security", "On improving information security” (1997), “On computer fraud and abuse" (1986), "On freedom of information" (1967), "On the coverage of government activities", "On the protection of personal secrets", "On secrecy" (1974), "On the right to financial secret” (1978), “On access to information on CIA activities" (1984), “On computer system security" (1987). These pieces of legislation regulate a wide range of consumer protection relationships in cyberspace.

It is interesting to compare the state of affairs regarding the regulation of internet consumer rights in the PRC. It is a widely recognized fact that China is the world leader in Internet commerce, given the country's tight control of the Internet. But the Law "On consumers' rights protection" of the PRC is characterized by leading Internet commerce innovations. In particular, the buyer has the opportunity to return the purchased product within seven days without giving any reason. The main thing that differentiates the legislative approach of the PRC from Ukraine is that this act separately specifies the requirements for the goods, provided that the buyer will not be able to return the goods. If the consumer has received a defective product or not the goods he/she has ordered, he/she has the right to submit a claim to the supplier. To do this, the company that owns the website through which the goods are sold, must provide the consumer with reliable information about the supplier, including its official name, legal address and methods of communication (Shabliienko, 2015; Shabliienko, 2018). 
If the e-commerce company does not have this information or provide false information, the consumer will not be able to submit a claim directly to the supplier. In this case, under the new rules, the buyer can submit a claim to the e-commerce company, which will have to consider and satisfy the substantiated claim. In the future, an e-commerce company may recover from the vendor all costs associated with satisfying the customer's claim (Harust et al., 2019c).

That means, that there is a worldwide tendency to regulate the sphere of Internet commerce in more detail, namely the protection of consumer rights, since the very structure and system of the Internet necessitates more detailed control. This control can be implemented in the form of oversight, as is the case in the US, or in the interfering with the process itself, as the PRC does.

Unfortunately, in Ukraine the examples of online shops like "ZakaZaka" make it clear that in our country the consumer has a very real opportunity to buy goods from entrepreneurs who violate the current legislation. However, given the "location" of the online store,
85

it is difficult enough to hold those responsible guilty.

Therefore, in our view, an effective way to prevent such offenders would be to block the domain. The proof of this is Presidential Decree No. 133 "On the application of personal special economic and other restrictive measures (sanctions)" (2017). This decree blocked a number of Russian websites in Ukraine. At one time, this decree was publicly criticized for blocking social networks used by quite a wide range of people. Of course, such blocking is quite easy to get around, but, as practice shows, despite the seemingly accessible VPN and other means of bypassing such blocking, the popularity of these sites among Ukrainians has fallen, and now they are used by fewer people. According to "Liga.Business", after blocking, the Russian Internet traffic lost about half of all users (Yurasov, 2018). Since the decree was published, the Ukrainian audience of Russian websites has dropped from 22.7 million to 9.1 million. The indicator reached the level of the Republic of Kazakhstan. According to "ain.ua", the audience of Russian Internet websites began to recover, with the share of Ukrainian 
traffic in the Internet continuing to fall. One possible explanation is that Ukrainian users have mastered VPN applications. According to the same data, the total traffic of Russian sites from countries such as the Netherlands, USA, UK and Germany has grown from 3 million to 4.7 million daily visitors. But even with such data it can be argued that only a fraction of users returned to these websites. From the data above, 12 million Ukrainian users have abandoned Russian online resources.

Presidential Decree No.133 dated April 28, 2017 (Decree of the President of Ukraine...2017) was a kind of sanction on the actions of the Russian Federation. In our case, these actions will be aimed primarily at consumer protection, since Internet users are now even minors who can simply make transactions in the Internet space. We also propose to create a database that should include information about websites that violate Ukrainian law. In general, there are two types of website blocking that providers now use to block a site. These include IP blocking, domain blocking, and URL blocking.

When blocking an IP address, the website owner can change the IP, bypassing the blocking and continuing his/her illegal activities. Domain blocking is more effective, but it also has certain aspects to consider when using this method. There are quite large web portals on which a lot of information is distributed, and in case of domain blocking, access to other information is impossible. The most effective in this regard is the combination of IP blocking and URL blocking. This not only blocks the website where the e-commerce entities were located and operated.

In our opinion, this step will help to improve the system of consumer rights protection. From the above data it becomes clear that this step will, first and foremost, alert e-commerce entities, ordinary users, as not everyone knows and understands what standards and characteristics a website should meet. Of course, it is quite easy to get around such a blockage, but such a bypass will be a conscious action of the user, so he will be aware that such actions endanger himself.

The solution to the problem of regulatory regulation of consumer protection in cyberspace is impossible at the national level. This situation is conditioned by the specifics of the 
existence and functioning of the Internet.

You cannot artificially localize the Internet, as there are a bunch of computer programs that counteract this lock. In our view, the only way out of this situation can be global cooperation to resolve this issue. At the national level, you can only reduce the problem and try to warn ecommerce participants. But such a practice is impossible without a proper legal framework.

The basis of the national legislation governing e-commerce is already in place, but the regulatory framework, which we currently have is not perfect, because most laws regulate only certain aspects and do not directly affect the Internet environment. In addition, it is worth noting that most of these regulations were adopted at the time of the formation of the Internet, so to compare the state of affairs that existed at the time of formation and the one that we are dealing with now is impossible. As noted above, ICT are rapidly evolving, directly affecting the ecommerce world and the vulnerability of the actors in these relationships.

\section{Conclusion}

The problem of legal regulation of public relations arising in the sphere of Internet concerning e-commerce in Ukraine was outlined above. In our opinion, there are three main ways to overcome this problem: 1) regulating social relations at the global level by the "soft law" method, 2) optimization of the national regulatory framework in the sphere of regulation of domestic cyberspace, 3) blocking websites that violate applicable law.

The development of domestic Internet commerce as well as public relations in its implementation is quite rapid, so the legislative and regulatory support of this sector of the economy requires the same rapid adaptation, because the existence of outdated regulations does not allow to regulate it effectively. For example, the Law of Ukraine "On information protection in information and telecommunication systems" dated 05.07.1994 № 80/94-BP, in our opinion, is not capable to regulate public relations arising in cyberspace in our time, since the fact of surface regulation is obvious issues that are intended to resolve this legal act. This approach is traced both to certain concepts and to a factual 
misunderstanding of information related to the obsolescence of the technologies during which this legislation was adopted.

Also, it should be noted that all normative acts related to the regulation of relations in cyberspace do not use the concepts characteristic of this type of relations and establish the general principles and the general procedure of actions. On the example of the online store "Zaka-Zaka", it was stated that they violate the current legislation of Ukraine. However, such actions are objectively conditioned. Since the acquisition of programs is not material, it deserves additional legal regulation. And this kind of relationship is only the beginning, since the further development of ICT causes the emergence of new social relations that are not effectively and timely regulated.

Therefore, we propose to take on the experience of the leading countries in the world and to amend the regulations. Article 9 of the Law "On consumers' rights protection" states that a buyer may substitute a good quality non-food item with another or obtain money in the absence of a similar product. However, this provision cannot be implemented in the case of a computer program transaction. These applications have individual alphanumeric keys that will no longer be valid if activated. The same question is relevant to the status of these goods in national law and needs to be addressed.

The Law "On E-Commerce" also needs to be amended. As noted earlier, a large proportion of Ukrainians use courier and mail services when ordering goods online. However, their law status is uncertain, so we propose to amend Article 6 of that law and equate the status of mail and couriers to the status of intermediate service providers.

Without proper control by the state on the implementation of the law, the proper functioning of the whole system is not possible, so we propose to adopt a normative legal act that would have the main purpose of creating a state body that would monitor the websites that violate the current legislation and block them.

\section{References}

Chaikovska VP. (2016). E-Commerce in Ukraine: Current State and Trends. Intelligence XXI, 3, 38-48. 
Decree of the President of Ukraine "On the application of personal special economic and other restrictive measures (sanctions)" No. 133. (2017, April 28). https://www.president.gov.ua/document s/1332017-21850.

Economic Code of Ukraine (2003, January https://zakon.rada.gov.ua/laws/show/43 6-15.

Factum Group (2019, October 11). https://inau.ua/sites/default/files/file/191 0/dani_ustanovchyh_doslidzhen_iii_kva rtal_2019_roku.pdf.

Fedorychak V. (2018). E-commerce in Ukraine 2018: figures, facts, interesting statistics. https://ag.marketing/ukru/elektronnaya-kommertsiya-vukraine-2018/.

Harust $\mathrm{Yu}$, Melnyk V, Kiiashko $\mathrm{Yu}$, Halunko V. (2019c). Economic crime, innovative mechanisms of counteraction by law enforcement agencies. Asia Life Sciences, 2, 145-162.

Harust Yu, Myrhorod-Karpova V, Pinchuk P. (2019b). Search for the ways to optimize the activities of state bodies managing the funds of international technical assistance. Asia Life Sciences, 2, 104-112.

Harust Yu, Zagorska D, Vashchenko S. (2019a). Problems of construction of the financial system of the state: organizational and legal aspects. Asia Life Sciences, 2, 63-69.

Law of Ukraine "On advertising" No. 270/96-VR. (1996, July 03). https://zakon.rada.gov.ua/laws/show/27 0/96-\%D0\%B2\%D1\%80/ed20030619.

Law of Ukraine "On banks and banking" No. 2121-III. (2000, December 07). https://zakon.rada.gov.ua/laws/show/21 21-14.

Law of Ukraine "On basic principles of information society development in Ukraine for 2007-2015" (2007, January 09).

https://zakon.rada.gov.ua/laws/show/53 7-16.

Law of Ukraine "On consumer protection" (2017, June 10). 
http://zakon.rada.gov.ua/laws/show/102 3-12\#n504.

Law of Ukraine "On consumer protection” No. 1023-XII. (1991, May 12).

https://zakon.rada.gov.ua/laws/show/10 23-12.

Law of Ukraine "On E-Commerce". (2015, September 03). https://zakon.rada.gov.ua/laws/show/67 5-19.

Law of Ukraine "On electronic digital signature" No. 852-IV. (2003, May 22). https://zakon.rada.gov.ua/laws/show/85 $2-15$.

Law of Ukraine "On electronic documents and electronic document management" No. 851-IV. (2003, May 22).

https://zakon.rada.gov.ua/laws/show/85 $1-15$.

Law of Ukraine "On financial services and state regulation of financial services markets" No. 2664-III. (2001, July 12). https://zakon.rada.gov.ua/laws/show/26 64-14.
Law of Ukraine "On information protection in information and telecommunication systems" No. 80/94BP. (1994, July 05). https://zakon.rada.gov.ua/laws/show/80/ 94-\%D0\%B2\%D1\%80.

Law of Ukraine "On insurance" No. 85/96- VR. (1996, March 07). https://zakon.rada.gov.ua/laws/show/85/ 96-\%D0\%B2\%D1\%80.

Law of Ukraine "On payment systems and funds transfer in Ukraine" No. 2346III. (2001, April 05). https://zakon.rada.gov.ua/laws/show/23 46-14.

Law of Ukraine "On protection of personal data" No. 2297-VI. (2010, June 01).

https://zakon.rada.gov.ua/laws/show/22 97-17.

Law of Ukraine "On telecommunications" No. 1280-IV. (2003, November 18). https://zakon.rada.gov.ua/laws/show/12 80-15. 
Myrhorod-Karpova V, Pchelina O,

Sezonov V, Zherobkina Ye. (2019).

Administrative and legal mechanism of execution of decisions of the European Court of Human Rights as the basis of case law application in the judicial system of Ukraine. Asia Life Sciences, 2, 34-49.

Official Consumer Confidence Index Statistics. GFK. (2018).

https://www.gfk.com/uk-ua/.

Order of the Ministry of Economy and Development of Ukraine "On approving the Rules of sale of goods on order and outside commercial or office premises" (2007, April 19). https://zakon.rada.gov.ua/laws/show/z1 181-07.

Poliakh VM, Kryvosheiev NM, Chuiko NV. (2017). E-Commerce: Theoretical and Legal Background and Current State of Ukraine. Science Rise, 5, 11-17.

Shabliienko AS. (2015). Legal regulation of e-commerce under the laws of the countries of the Anglo-American system of law. Bulletin of the Academy of Advocates of Ukraine, 1(32), 44-52.
Shabliienko AS. (2018). Public administration of electronic commerce in accordance with the laws of some Asian countries. Legea Si Viata, 1, 4953.

The Civil Code of Ukraine (2003, January 16). https://zakon.rada.gov.ua/laws/show/43 5-15.

The number of Internet users in Ukraine is increasing. (2019, February 17). https://news.finance.ua/ua/news//443742/kilkist-internet-korystuvachivv-ukrayini-zbilshylas-infografika.

Yurasov S. (2018). More than a half. How Runet lost Ukrainian traffic. https://biz.liga.net/all/it/article/bolshepoloviny-kak-runet-poteryal-ukrainskiytrafik.

Zadorozhnyi Z. (2017). E-commerce in Ukraine: Discussion Aspects of Legal Regulation. Вісник Ternopil National Economic University, 1, 119-126.

Zhylenko D. (2018). Rating of popular sites for April 2018. https://tns- 
ua.com/news/reyting-populyarnih-

saytiv-za-kviten-2018.

Zhylenko D. (2019). Online shopping in Ukrainian: the more often Ukrainians buy online and what stops them from buying online in 2018. https://tnsua.com/news/on-line-shopping-poukrainski-chto-chashhe-ukraintsyipokupayut-on-line-i-chto-ihostanavlivaet-ot-internet-pokupok 